\title{
追踪地质时期的浅海红层一一上扬子区志留系 下红层为例
}

\author{
戎嘉余，王怿，张小乐
}

现代古生物学和地层学国家重点实验室, 中国科学院南京地质古生物研究所, 南京 210008

*E-mail: jyrong@nigpas.ac.cn

收稿日期: 2011-08-03; 接受日期: 2012-02-08

中国科学院创新工程重要方向项目(编号: KZCX2-YW-Q05-01)、国家重点基础研究发展计划项目(编号: 2012CB821901)和国土资源部中 国地质调查局(编号: 1212011120116)资助

\begin{abstract}
摘要 海相红层在我国地质记录中颇为常见, 它的空间分布大致可归纳为大洋盆地深水、 远岸较深水和内陆棚浅水等 3 种类型. 华南志留系主要发育兰多维列统特列奇阶下部、上部 和罗德洛统上部 3 套海相红层. 基于以往的工作，本文根据滇黔川湘鄂渝近百个县、200 余个 剖面或点的资料, 追踪上扬子区下特列奇阶浅海红层(溶溪组及其部分相当地层, 俗称下红层) 的时空分布. 这套红层为紫红与黄绿或蓝灰色相间的泥岩、粉砂岩夹细砂岩, 在华夏古陆西北 侧和滇黔古陆北侧尤为发育, 一般近古陆者厚度大, 远离者减薄至消失; 古陆的存在是其形 成的古地理背景, 由河流携带的大量含高价铁的细碎屑物是沉积物的来源, 堆积在拥有氧化 作用的近陆海底上, 当时处于海退态势、海水局部淡化、缺乏上升洋流、营养物质贫瘦、有 机生产量低、海盆下沉、沉积速率较快. 它既与欧洲同期和华南奥陶纪的远岸较深水红层不 同, 更与藏南很深、很静、沉积速率很慢、环境稳定的白严系大洋红层不一样. 夯实生物地层 基础, 开拓岩石矿物、沉积、地球化学、古地理、古海洋、古气候、大地构造等学科的交叉 研究, 对于揭示浅水海相红层广布期的地球系统演变是必不可少的.
\end{abstract}

关键词

华南

志留纪早期

浅水海相红层

时空分布

氧化环境
海相红层在我国地层记录中并不少见, 虽说它 在各地、各期的沉积类型、成因、古地理和构造背景 较为复杂, 但从地理位置和沉积特征分析, 大致可归 纳为 3 种类型: 1) 大洋深海沉积, 如藏南白严系-第 三系 $\left.{ }^{[1 ~ 9]}, 2\right)$ 陆棚或陆表海远岸较深水沉积, 如华南 扬子地台奥陶系紫台组 ${ }^{[10 \sim 14]}$, 3) 近岸浅水沉积, 如

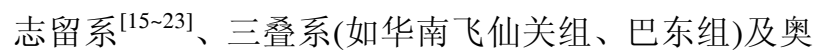
陶系(如滇东红石崖组、黔中“湄潭组”和浙西红家坞 组). 中、上元古界也发育海相红层, 但研究甚少. 就
上述第三类而言，不同地质时期海相红层的岩石特 征相似甚或酷似, 多以紫红色颗粒细的泥岩和粉砂 岩为主, 难怪早年德国地质学家李希霍芬在川陕边 境考察时, 因三叠系飞仙关组的红层岩性与志留系 的相似而误定其时代为志留纪 ${ }^{[23]}$, 暗示了它们在成 因上可能存在着某种联系. 相比较而言, 以往对海相 红层的探究不如对黑色页岩那么重视 ${ }^{[24]}$, 对古生代 海相红层的研究不如对中新生代的那样深入 ${ }^{[1 \sim 9]}$.

志留系海相红层在我国分布较广，除了钦防等

英文引用格式: Rong J Y, Wang Y, Zhang X L. Tracking shallow marine red beds through geological time as exemplified by the lower Telychian (Silurian) in the Upper Yangtze Region, South China. Sci China Earth Sci, 2012, 55: 699-713, doi: 10.1007/s11430-012-4376-5 
地区可能发育温洛克统的深水红层外 ${ }^{[25]}$, 主要是浅 水成因的, 如华南(扬子区和江南区 $)^{[16,18,22] \text { 、塔里 }}$ 木 $^{[26] \text { 、祁连山、宁夏 }}{ }^{[10,27]}$ 等地. 以上扬子区为例, 志 留系的浅水红层主要有 3 套: 1) 兰多维列统特列奇阶 下部(lower Telychian), 2) 特列奇阶中上部(mid-upper Telychian), 和 3) 罗德洛统上部(upper Ludlow)(图 1), 以第一套分布最广. 在黔川湘渝鄂边区的地质普查 中, 兰多维列统的这两套红层分别被称为下红层(如 溶溪组)和上红层(如迴星哨组 $)^{[15,18,28] 1)}$, 或一红层和 二红层 ${ }^{[22]}$. 从生物演化阶段看, 它们恰好被含丰富广 布和独具特色的“秀山动物群”的地层(如秀山组)所分 隔, 尽管该动物群的分子可以上延到迴星哨组. 滇

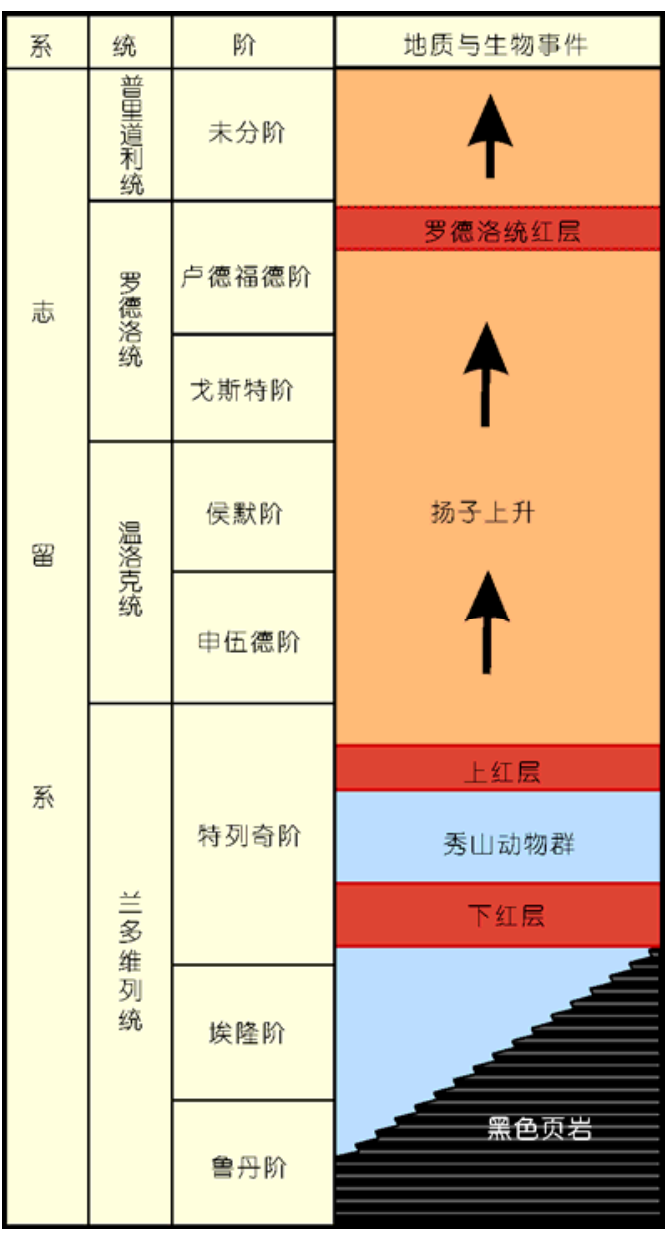

图 1 上扬子区志留系年代地层划分、3 套浅水海相红层及 其与黑色页岩、秀山动物群和扬子上升的关系
东元江-曲靖至黔西赫章一带的关底组, 也发育浅海 红层, 曾因认识有误而被对比到黔川湘鄂诸省的上 红层 (迴星哨组) ${ }^{[17,29]}$. 实际上, 关底组的层位比上红 层高得多, 属于上述所说的第三套海相红层 ${ }^{[23,30]}$, 时 代为罗德洛世晚期.

溶溪组以紫红色细碎屑岩的出现与消失作为底、 顶界, 以紫红色和黄、灰绿或蓝灰色相间(有时被描记 为杂色)泥岩、粉砂岩夹细砂岩为特征(图 2), 是典型 的岩石地层单位. 溶溪组在不同地点含多层红层, 其 单层厚度一般在 2 10 $\mathrm{m}$ 之间; 各地下红层的厚度差 别很大, 多在 100 300 m 之间, 最厚的超过 $500 \mathrm{~m}$; 厚度小于 $100 \mathrm{~m}$ 的通常被包括在韩家店组、纱帽组等 之内. 这些下红层到达分布边缘后便迅即消失, 相变 成黄-灰绿色地层, 其他岩性大同小异. 下红层尽管 穿时且绝大多数层位缺少宏体和微体化石, 但因颜 色醒目, 易于识别, 时限不长, 层位大致稳定 ${ }^{[15]}{ }^{1)}$, 野外追踪的优势突出. 1959年北京地质学院师生在鄂 西(如咸丰、恩施、五峰图幅)地质填图时最早认识到 这一点(如 1968 年 1:20 万咸丰幅地质图和区域地质 报告).上世纪黔川湘鄂诸省在编制 1:20 万相关图幅 报告时，也都把下红层作为对比的标志 ${ }^{[31 ~ 33] 1,2)}$.

在上扬子区，属于下红层的岩石地层单位(如溶 溪组、大关组嘶风崖段、王家湾组), 虽说称谓不一, 时限有别, 但均宜归于下特列奇阶 (见本文“时代讨 论”一节). 黔北、川南的韩家店组和鄂西的纱帽组多 以黄绿色细碎屑岩为主, 间夹较薄的红层, 后者似与 下红层(下部)遥相呼应.下红层所含化石(多见于黄 绿色岩层中, 红层中极少)经常数量不丰、多样性很 低 ${ }^{[15]}$, 根据局部地段所产化石的门类(如双壳类和舌 形贝类，属种单调)分析，推测均属于近岸、浅水(以 BA1 为主) 的生物群落 ${ }^{[34-37]}$.

葛治洲等 ${ }^{[15]}$ 和 Rong 等 ${ }^{[23]}$ 对下特列奇阶海相红 层分别根据 44 个和近 60 个剖面点的资料 ${ }^{[15]}$ 制作了 其分布的两幅图件. 本文的研究基础, 除上述工

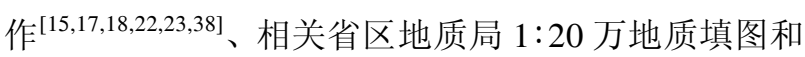
笔者及其他同仁近 15 年来的野外调查之外, 还包括 去年两位年轻作者专赴鄂西和湘西北野外考察时所

1) 王立亭. 贵州的志留系. 贵阳: 贵州省革命委员会地质局, 1976. 68

2) 四川省地质局综合研究队. 四川省地层总结. 成都: 四川地质矿产局, 1978. 331 

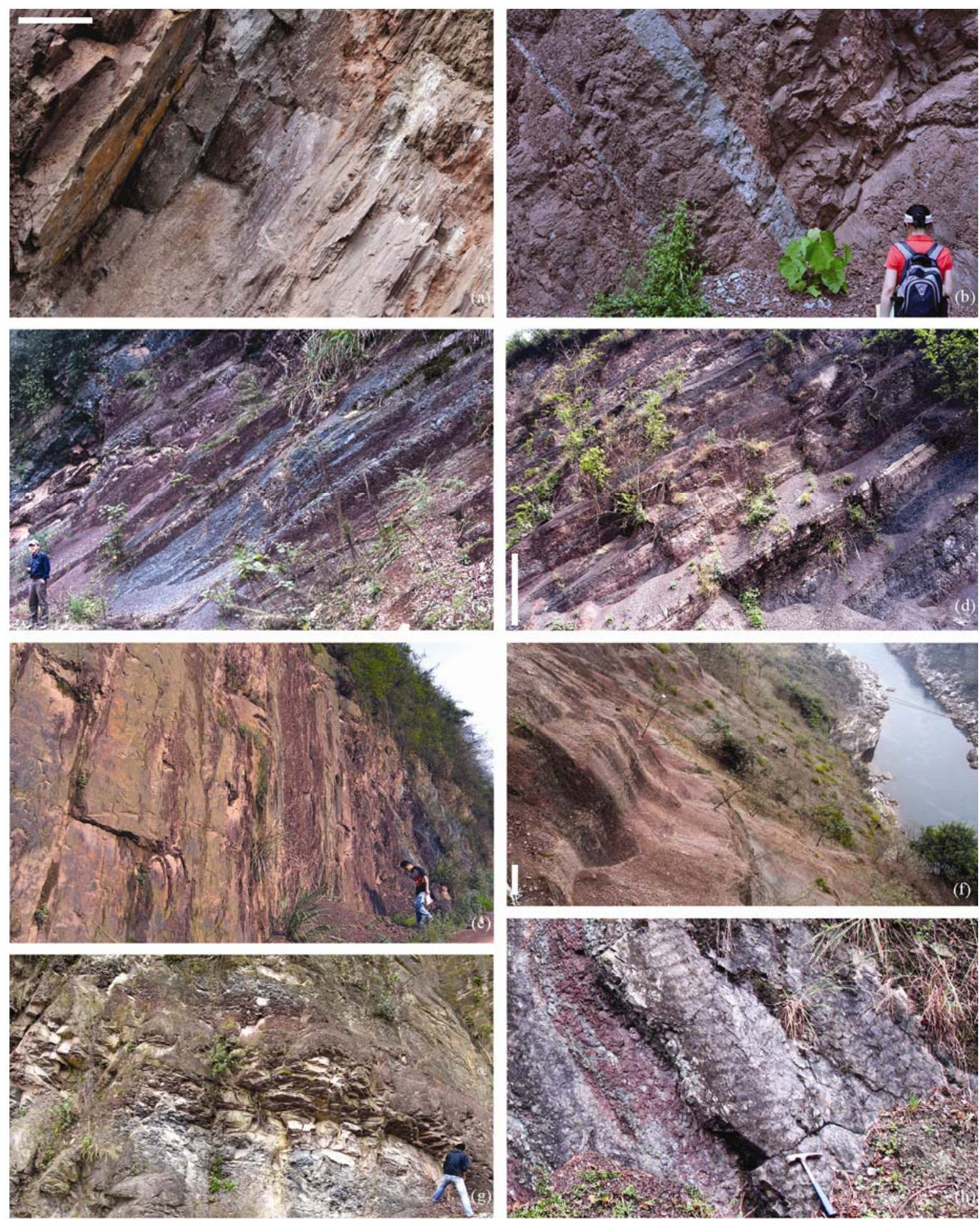

图 2 黔渝湘鄂边区志留系下特列奇阶浅水海相红层溶溪组(下红层)的野外剖面及其相关层位

(a), (b) 重庆秀山溶溪的溶溪组(命名剖面) ((a) 黄绿色粉砂岩夹紫红色和蓝灰色泥岩, 比例尺为 $1 \mathrm{~m}$; (b) 紫红色泥岩夹蓝灰色泥岩). (c) 湖南 张家界温塘剖面, 溶溪组紫红色泥岩夹蓝灰色泥岩. (d) 湖南慈利岩泊渡镇失马村剖面, 溶溪组紫红色泥岩夹蓝灰色泥岩, 比例尺为 $2 \mathrm{~m}$. (e) 湖南石门矿厂剖面, 溶溪组紫红色泥岩夹黄绿色泥岩、粉砂岩. (f) 贵州仁怀沙滩剖面, 韩家店组的紫红色泥岩夹黄绿色泥岩、粉砂岩, 比例 尺为 $2 \mathrm{~m}$. (g) 湖北长阳平洛剖面, 纱帽组的黄绿色粉砂岩夹紫红色泥岩. (h) 贵州石阶雷家屯剖面, 溶溪组紫红色泥岩, 层面上发育浅水波痕 
获得的新资料. 根据 5 省、 1 市(滇黔川湘鄂渝)、近 百个县、 213 个(包括发育下红层的 176 个和不含下红 层的 37 个)剖面点的有关岩石、地层和古地理资料分 析, 本文着重追踪下红层的时空分布, 初步探索其沉 积条件和形成环境, 为史前浅水海相红层研究提供 实例.

\section{1 地理分布}

图 3 显示上扬子区的下红层主要分布在 $\mathrm{A}, \mathrm{B}$,
$\mathrm{C}$ 和 $\mathrm{D}$ 四个区域. 以下简释上述各区下红层的分布特 点.

\section{1 华夏古陆西北侧和黔中古陆北侧区(图 3-A)}

下红层分布于华夏古陆西北侧和黔中古陆北侧, 大部分称溶溪组，也可包括在韩家店组(如黔北)、纱 帽组(鄂西)、翁项组(黔东南)和高寨田组(黔中)的一部 分. 这是扬子区下特列奇阶浅水红层最发育、分布范 围最大、研究或报道最多的地区，其中，尤以黔渝湘 鄂边区发育最好，笔者选择其中的 6 个剖面作为下红

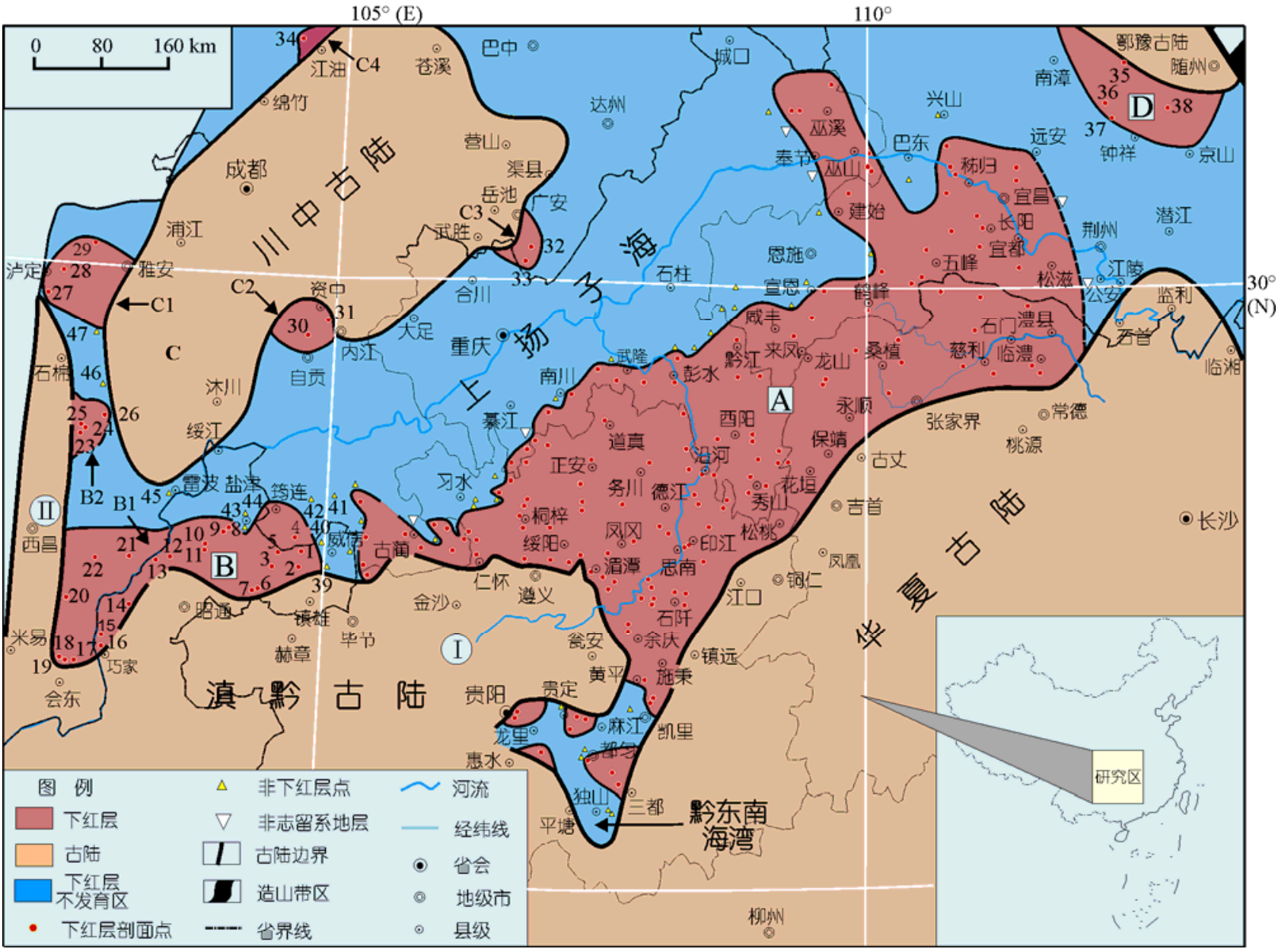

图 3 上扬子区志留系下特列奇阶浅水海相红层的地理分布图

A. 华夏古陆西北侧和黔中古陆(I)北侧区(含黔东南海湾), 相关信息见图 5. 红层剖面: B1-滇黔古陆北侧区(1 22). 1, 威信苏麻坪(104 m: 下 红层厚度, 下同); 2, 3, 镇雄两河口、杉树乡; 4, 笴连落木柔 $(50 \mathrm{~m}) ; 5 \sim 7$, 彝良芭蕉窝、芦塘沟、银厂沟 $(128 \mathrm{~m}) ; 8$ 11, 大关黄荆坝、老母城、 岔河、黄葛溪; 12,13 , 永善莲峰、大兴; 14, 鲁甸埂底; 15,16 , 巧家安溪、烂田坝; 17 19, 会东新街、放马坪 (67 m)、黄柏; 20, 普格干田(122 m); 21, 金阳新寨子; 22 , 布托县城边(约 $100 \mathrm{~m}$ ). B2 康滇古陆(II)东北侧区(23 26). 23, 24, 越西下普雄(48 m)、碧鸡山(42 m); 25, 26, 甘洛敏子 洛木、波波乡.C. 川中古陆周缘区(27 34). C1: 27, 28, 泸定兴隆、二郎山(48 m); 29, 天全龙门; C2: 30, 威远井下县城边 $(8.5 \mathrm{~m}) ; 31$, 资中银山; C3: 32, 33, 华菳红岩煤矿 $(30 \mathrm{~m})$ 、李子垭 $(50 \mathrm{~m}) ; \mathrm{C} 4: 34$, 江油巩家. D. 鄂豫古陆南侧区(35 38). 35, 湖北宜城板桥店; 36 38, 钟祥胡集、朱堡 埠、客店. 非红层剖面: 39,40 , 云南威信滑石板、狮子沟; 41, 42, 四川兴文新街、玉河; 43,44 , 盐津黄桷槽、文昌宫; 45 , 雷波帕哈; 46, 甘洛 岩岱; 47, 汉源白沙沟 
层的典型或代表性剖面(图 4).

本区下红层的分布情况如下:

（1）黔西北、川西南. 古萄水潦堡的下红层略超 过 $20 \mathrm{~m}^{[39]}$; 兴文古宋、古萄城西南和马盐滩 ${ }^{[0]}$ 、习 水下河坝北约百米处的下红层分别为 $15,5,5$ 及 $4 \mathrm{~m}$; 古萄背斜西端的下红层减薄至 $2 \mathrm{~m}$ (据叙永幅区域地 质报告); 毕节沟头下红层仅厚 $1.3 \mathrm{~m}$ (据桐梓幅区域 地质报告); 上述地区均靠近下红层分布边缘. 长 宁背斜北翼(如双河) ${ }^{[41]}$, 兴文县城北文昌宫(据叙永 幅区域地质报告)，叙永海坝场沙田头 ${ }^{[39]}$ ，古落鱼化、 大坪, 习水下河坝、桑木场、土河场、温水等地(据遵 义、桐梓、威信等幅区域地质报告), 下红层均踪影全 无.

(2) 黔北、渝南. 笔者考察綦江、道真、正安、 绥阳、桐梓、习水、仁怀、遵义、涺潭等县境的相关 地层后, 测得正安(黄家屋基、严家寨、乐俭米粮村、 土坪关口)和绥阳(温泉、枕坝)的下红层(韩家店组中 段)厚度多在 30 60 $\mathrm{m}$ 之间. 桐梓城东黑石溪和三岔 的下红层超过 $80 \mathrm{~m}$ (据桐梓幅区域地质报告). 仁怀沙 滩 $(19 \mathrm{~m}) 、$ 桐梓茅坝(约 $15 \mathrm{~m}$ )和松坎韩家店 $(7 \mathrm{~m})^{[42]}$ 的下红层均不厚. 遵义永乐高家崖紧临黔中古陆, 下 红层只有 $0.2 \mathrm{~m}$, 是已知下红层最薄之处. 道真巴渔 的韩家店组中下部发育紫红色泥岩属于下红层, 其 顶部的紫红色泥岩也被与溶溪组对比 ${ }^{[31] 2)}$. 武隆县境 的情况在早年地质考察中能寻找到蛛丝马迹: 永顺 乡(今长坝镇)沙碥和卡子场矿洞崖两处, 韩家店组顶 部都发育较薄的紫红和灰绿色页岩 ${ }^{[43]}$, 笔者疑其为 下红层, 使其与綦江观音桥 $(8 \mathrm{~m}$ )、南川三泉(小于 $5 \mathrm{~m}$ ) 和武隆白马(笔者观察)一起进入了下红层分布的边 缘区.

(3) 黔东北、渝东南和湘西北. 这是上扬子区下 红层最发育的地区，东界为华夏古陆(铜仁、吉首、桃 源、江陵一线以东, 此界细节所知甚少). 石阶雷家 屯、印江合水、松桃董家坪、秀山溶溪、西阳龙潭、 保靖卡棚、张家界温塘到龙山红岩溪这一北东、南西 向凹陷条带里, 溶溪组尤为发育 ${ }^{[15]}$, 厚度多在 150 300 m 间, 个别的逾 $500 \mathrm{~m}^{[44]}$. 松桃-秀山一带的 溶溪组常分成 3 部分：上部和下部以紫红色泥岩为主, 中部为紫红与黄绿色泥岩互层(据沿河、西阳、黔江、 永顺、桑植等幅区域地质报告). 由秀山向西、向北,
下红层厚度骤减，如酉阳龙潭到彭水万足，从 200 多 米骤减至 $15 \mathrm{~m}$; 彭水郁山、石柱漆辽河和黔江濯水坝 向北(据黔江幅区域地质报告), 下红层了无痕迹 ${ }^{[29]}$. 这套红层有称为杂色地层或彩色页岩(如慈利、石 门) $)^{[45]}$.

（4）黔中、黔东南. 志留纪时, 位于黔东南海湾 内, 志留纪地层发育情况复杂, 如发育底砾岩, 下红 层中出现灰岩层, 相距不远的剖面地层特征很不相 同，顶界差别很大等 ${ }^{[46] 1,3)}$. 贵阳乌当落水冲和田坝 头的高寨田组下部发育紫红色泥岩 ${ }^{1)}$. 下红层距志留 系底界在田坝头仅 $6 \mathrm{~m}^{[46]}$, 在乌当后所厚达百余米 ${ }^{[47]}$, 说明海侵前此地的地形相差较大. 贵阳打渔寨的下 红层不足 $25 \mathrm{~m}^{[48]}$; 贵定城东约 $12 \mathrm{~km}$ 的马家屯 ${ }^{[49]}$ 和 龙里羊场也发育下红层, 但细节不明. 凯里以东翁项 的翁项组下部含多层紫红色泥岩, 所夹生物灰岩产 浅水珊瑚 ${ }^{[50]}$, 与滇东北嘶风崖段所产者不同 ${ }^{[51]}$. 都 匀王司和三都四十寨的翁项组下部夹很薄的紫红色 泥岩 ${ }^{[47]}$. 凯里以西洛棉的翁项组下部, 都匀以西的邦 水、钱家坡、马场坪, 均未见下红层 ${ }^{[47]}$; 独山县境也 如此，都越过了下红层分布的南界.

(5) 鄂西南、鄂西. 宣恩高罗的溶溪组逾 300 $\mathrm{m}^{[15]}$; 利川忠路西南纱帽组下部发育很薄的紫红色 页岩 ${ }^{[52]}$; 咸丰火龙坪、宣恩晓关与椒园、建始官店口、 恩施太阳河至巴东思阳桥, 下红层全然不见 ${ }^{[15,46]}$. 剓 归杨林、长阳三洞水等地纱帽组含紫红色泥岩、粉砂 岩(据长阳、巴东幅区域地质报告) ${ }^{[53]}$. Yin ${ }^{[40]}$ 记述过 “枝江” 以南土地均纱帽组中发育红层, 经查核, 此 “枝江”非今日之枝江市(该市南部地表出露的地层是 第四系)，实为宜都县枝城镇(旧称枝江)，其南约 10 $\mathrm{km}$ 观音桥等地确实出露志留系, 纱帽组中的下红层 至多百米(据长阳幅区域地质报告). 据王怿、张小乐 最近野外考察，宜都茶园寺或土地岭与上述地点靠 近，下红层也不足百米; 向北至长阳大堰和巴山坳, 下红层厚度减至 $50 \mathrm{~m}$ 以下; 到鹤峰下坪, 只剩 $8 \mathrm{~m}$. 宜昌大中坝和兴山大峡口纱帽组中的紫红色粉砂质 泥岩厚度更小 ${ }^{[15,54]}$, 已临近下红层分布之边缘.

(6) 渝北. 巫溪徐家坝的韩家店组(厚 $105 \mathrm{~m}$ )中 下部为黄绿色粉砂岩、泥岩层(厚 $64 \mathrm{~m}$ ), 其中夹两层 厚 10 和 $17 \mathrm{~m}$ 的紫红色粉砂质泥岩(据巫溪幅区域地 质报告); 向西到新店、白果, 减薄至只剩 5 7 m; 它

3) 金淳泰. 西南地区地层总结, 志留系. 成都: 地质部成都地质矿产研究所, 1982.135 


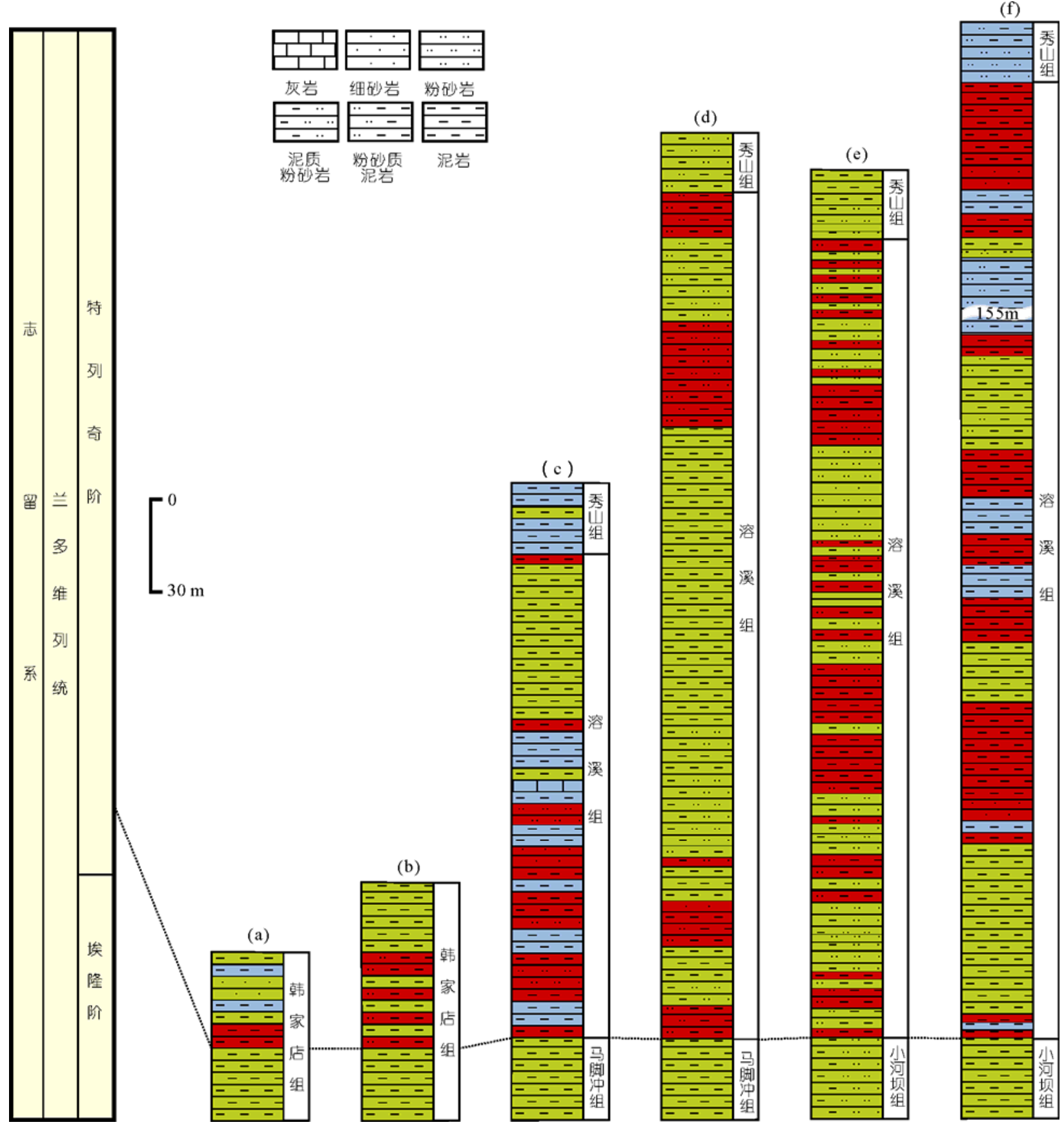

图 4 上扬子区志留系下特列奇阶 6 条重要剖面浅水海相红层的柱状对比图

(a) 黔北桐梓韩家店; (b) 黔北绥阳后坝; (c) 黔东北务川龙井坡; (d) 黔东北印江合水; (e) 渝东南秀山溶溪; (f) 湘西北龙山比洞. 下红层或在 韩家店组中下部((a), (b))或为溶溪组全部((d) (f))

们与命名地点的下红层遥相呼应; 再向西到田坝则 完全被灰绿色泥岩代替. 渝北的下红层是否与渝鄂 湘边区的溶溪组在时空分布上存在联系? 目前还有 问题，皆因湖北五峰、建始和巴东之间的三角形地表
被三叠纪地层盖覆，不清楚地表下是否发育志留系 下红层, 有待查证.

根据上述，本区下红层的分布包括以下若干特 点: 
（1）与古陆的关系. 华夏与滇黔两个古陆再次联 合后, 下红层在它们的北侧成片发育, 迄今尚未发现 这套下红层呈孤立状态分布(即被黄绿色岩层所包围) 的例子(图 3). 近陆源区的生物多样性甚低且含量少, 它们显然是在近岸浅水海底沉积的, 与深水红层的 成因相去甚远 ${ }^{[5,55 ~ 57]}$. 塔里木盆地西缘、祁连山和宁 夏志留系特列奇阶的海相红层与上扬子区的有许多 类同之处.

（2）分布型式. 下红层临近古陆者, 紫红色岩层 的厚度最大、层数最多; 远离者红层的总厚度渐次减 薄、层数减少, 直至消失 ${ }^{[15,16,18 \sim 20]}$ (图 5).

距离华夏古陆最近的地点, 如张家界温塘, 溶溪 组厚度超过 $500 \mathrm{~m}$, 为下红层已知最厚的地点之一. 龙山红岩溪、酉阳小咸等地, 下红层也很厚(多在 500 400 m 之间); 再向西, 下红层总厚在 400 100 m 间摆动; 有些地方的下红层逐渐或骤然减薄至不足 $100 \mathrm{~m}$. 产生这些变化的原因可能部分与离开古陆的 远近有关. 到靠近下红层分布的边缘区 (如黔北仁怀 沙滩、桐梓茅坝和韩家店、习水下河坝以北, 渝南綦 江观音桥、南川三泉; 鄂西宜昌大中坝和兴山大峡口 等), 厚度只剩下 15 30 m. 到下红层分布的最边缘 (如毕节沟头), 厚度只有 $1 \sim 2 \mathrm{~m}$. 下红层已知最薄处 在遵义永乐高家崖(韩家店组里的红层, 只有 $0.2 \mathrm{~m}$ ), 而在风冈躯川, 韩家店组里的红层单层数量多、厚度 较大. 再向外侧延伸(如黔西北习水, 渝南彭水、石柱 和黔江黎水, 鄂西宣恩椒园、恩施太阳河、鹤峰官店 口, 渝北巫溪田坝, 鄂西巴东思阳桥、兴山古夫等), 下红层消失殆尽, 被黄绿色细碎屑岩替代. 图 5 展示 了 A 区下红层的古地理和厚度分布情况, 进一步证 实了它与古陆之间的密切关系.

(3) 靠近华夏古陆的湘西北、黔东北、渝东南是 下红层最发育的地区，厚度也最大(300 500 m)(图 5); 首先是湘西北的保靖、永顺、龙山、桑植、慈利等县 境, 分布最广; 其次是黔东北的印江-沿河(300 400 $\mathrm{m}$ )一带, 范围较窄.

(4) 黔北、渝南和鄂西, 下红层的厚度相对稳定, 大都小于百米(图 5). 当时这两个地区沉积底域相对 平坦、沉降速率比较低缓, 距离华夏古陆较远.

(5) 渝北的巫溪、巫山到鄂西的建始(以北)这样
一个北西-南东向条带, 距离华夏古陆较远, 仍有下 红层分布，却完全突出于成片分布区之外(图 5); 而 鄂西的宣恩、恩施、利川和建始(以南)及兴山、巴东 一片, 志留系紫红色地层全然不见，下红层的分布呈 现这么一个格局, 令人颇为费解.

（6）黔东南海湾的下红层，零星分布在 4 个孤立 小区，即贵阳以东、龙里东南、福泉以南、都匀和三 都间(图 5), 各自都紧挨着古陆, 厚度不大, 研究程度 有限.

\section{2 滇黔古陆北侧区(图 3-B)}

下红层主要分布在滇东北, 如大关(黄葛溪)、彝 良(小干溪)、盐津(县城南 $22 \mathrm{~km}$ 发育不厚的紫红色泥 岩) ${ }^{[58]}$, 永善、鲁甸、巧家县境北部(金塘的下红层厚 约 $30 \mathrm{~m}$ ), 威信苏麻坪和大关双河岩头上(下红层有 3 层, 各层厚度不足 $10 \mathrm{~m}$, 间夹灰黄绿色的泥岩粉砂 岩或生物灰岩)(威信幅、镇雄幅区域地质报告)。下红 层的分布也进入到川西南(图 3-B1，B2), 如筠连县境 南部(嘶风崖段), 城东南的落木柔较薄, 城西南的更 薄 ${ }^{[40]}$.

在大关黄葛溪(大关组嘶风崖段的命名地), 嘶风 崖段的中下部为灰色泥质条带灰岩、泥岩夹灰岩, 产

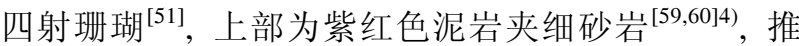
测它与溶溪组部分相当 ${ }^{[18]}$. 永善团结附近, 石门坎组 (大致相当于石牛栏组)之上被划归入到“上统”(罗德 洛-普里道利统)(雷波幅区域地质报告), 可能属于下 特列奇阶, 其甚薄的紫红色地层也说明已靠近下红 层分布边缘. 川西南的布托、普格、宁南、会东、金 阳等县境内也发育下红层(西昌幅等区域地质报 告 ${ }^{[29]}$. 康滇古陆西侧越西县城以东的碧鸡山一带的 下红层，厚度在 10 50 m 间. 鉴于威信狮子沟(笔者 考察)、大石板(威信幅区域地质报告)到双河一带未见 下红层踪迹，故在图 3 中将 $\mathrm{A}$ 和 $\mathrm{B}$ 两区隔断. 根据同 理，我们将 $\mathrm{B} 1$ 和 $\mathrm{B} 2$ 隔断. 盐津县城北 $2 \mathrm{~km}$ 处 ${ }^{[58]}$ 以 及威信、兴文、筠连、雷波、甘洛、美姑等县境内，下 红层多缺失而被黄绿色地层替代. 据笔者观察, 永善 大兴(临近金沙江)志留系最高层位只到黄葛溪组，往 上包括下红层等志留纪地层都不发育. 推测本区下 红层沉积可能受控于康滇和滇黔两个古陆(图 3-B2), 而与川中古陆(图 3-C)的关系不大.

4) 郭文魁, 黄劭显. 云南盐津大关彝良间地质矿产. 前矿产测勘处临时报告, 1942.17 


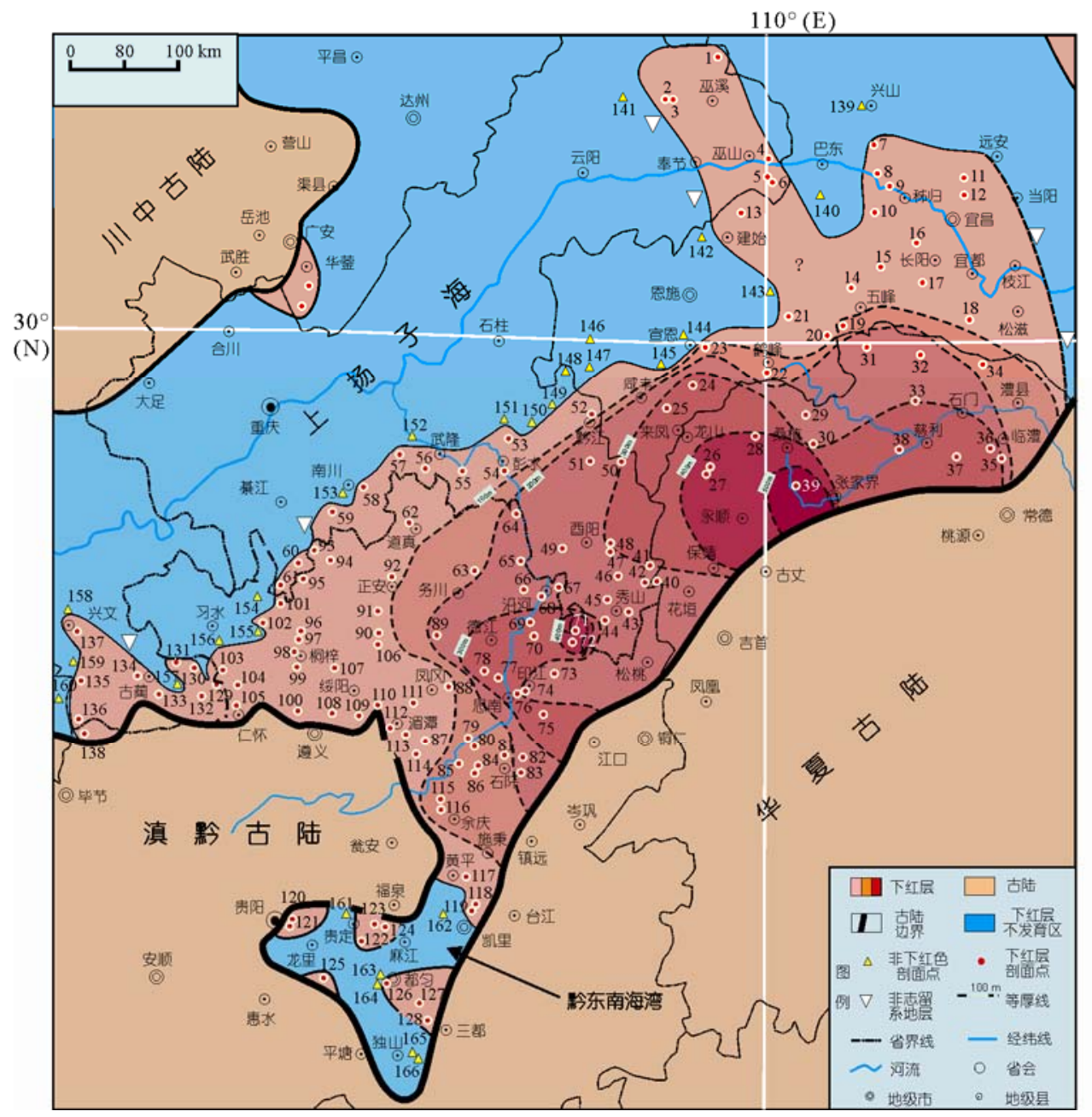

图 5 上扬子区 $\mathbf{A}$ 区志留系下特列奇阶下红层的古地理与厚度分布图

下红层剖面(厚度): 1 3, 巫溪徐家坝 $(67 \mathrm{~m}$ )、新店、白果; 4 6, 巫山横石溪、抱龙河、桃花; 7, 兴山大峡口; 8 10, 䄰归新滩、庙河、杨林; 11,

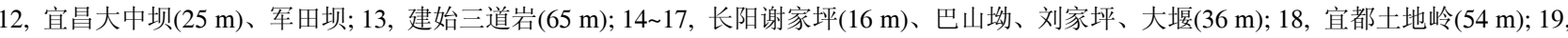
20, 五峰香樟坪 $(140 \mathrm{~m}) 、$ 湾潭 $(27 \mathrm{~m}) ; 21,22$, 鹤峰龚家垭 $(8 \mathrm{~m}) 、$ 官屋 $(138 \mathrm{~m}) ; 23,24$, 宣恩两河口、高罗 $(343 \mathrm{~m}) ; 25$, 来风三堡; 26, 27, 龙山 红岩溪、比洞 (467 m); 28 30, 桑植陈家河(414 m)、淋溪河 $(201 \mathrm{~m}) 、$ 洪家峪(283 m); 31 33, 石门龙池河(270 m)、庚子山(283 m)、龙王洞(297 m); 34, 澧县火连坡 $(181 \mathrm{~m}) ; 35,36$ ，临澧太浮山、文家 (>313 m); 37，桃园茅草铺; 38，慈利失马溪 $(375 \mathrm{~m}) ; 39$, 张家界温塘(529 m); 40, 花垣卡 棚(246 m); 41 46, 秀山石堤、小 Y口、胡家洞、长岗 $(280 \mathrm{~m})$ 、溶溪 $(240 \mathrm{~m})$ 、妙泉 $(265 \mathrm{~m}) ; 47 \sim 50$, 酉阳龙潭 $(>235 \mathrm{~m}) 、 卜$ 海 $(260 \sim 330 \mathrm{~m})$, 丁 市 $(250 \mathrm{~m}$ )、小咸(250 330 m); 51, 52, 黔江濯水 $(250 \mathrm{~m})$ 、城北(约 $40 \mathrm{~m}) ; 53,54$, 彭水龙射南 $(40 \mathrm{~m}) 、$ 万足 $(15 \mathrm{~m}) ; 55 ~ 57$, 武隆江口 $(17 \mathrm{~m}) 、$ 龙 洞崖、长坝; 58, 南川三泉; 59, 万盛姐谷坪 $(13 \mathrm{~m}) ; 60,61$, 綦江观音桥 $(8 \mathrm{~m})$ 、龙门峡; 62, 道真巴渔 $(64 \mathrm{~m}) ; 63$, 务川龙井坡(152m); 64 70, 沿 河洪渡 $(297 \mathrm{~m})$ 、思渠、官舟、李溪、县城边、甘溪 $(>300 \mathrm{~m}) 、$ 谯家镇 $(381 \mathrm{~m}) ; 71,72$, 松桃甘龙、董家坪 $(455 \mathrm{~m}) ; 73 \sim 75$, 印江合水 $(268 \mathrm{~m})$ 、 周家坝 $(270 \mathrm{~m}) 、$ 缠溪 $(348 \mathrm{~m}) ; 76 \sim 80$, 思南凉水井 $(348 \mathrm{~m}) 、$ 鸭武溪、东华溪 $(310 \mathrm{~m})$ 、半边 $(136 \mathrm{~m})$ 、㸗溪; 81 86, 石阶雷家屯 $(180 \mathrm{~m}) 、$ 凯跃 $(245$ $\mathrm{m})$ 、枫香坪 $(200 \mathrm{~m})$ 、均田坝 $(160 \mathrm{~m})$ 、本庄 $(130 \mathrm{~m})$ 、白沙; 87 89, 凤冈躯川 $(36 \mathrm{~m})$ 、硐卡拉 $(73 \mathrm{~m})$ 、八里溪 $(240 \mathrm{~m}) ; 90 \sim 92$, 正安土坪 $(53 \mathrm{~m})$ 、 乐俭 $(50 \sim 60 \mathrm{~m})$ 、黄家屋基 $(95 \mathrm{~m})$; 93 100, 桐梓坡渡 $(3 \mathrm{~m})$ 、摆伞溪 $(15 \mathrm{~m})$ 、韩家店 $(8 \mathrm{~m})$ 、新场 $(5 \mathrm{~m}) 、$ 凉风垭、黑石溪(86 m)、戴家沟 $(59 \mathrm{~m})$ 、 三叉(42 m); 101, 102, 习水下河坝 $(5 \mathrm{~m})$ 、双龙场 $(10 \mathrm{~m}) ; 103 \sim 105$, 仁怀沙滩 $(19 \mathrm{~m})$ 、杨村 (40 m)、中枢 (40 m); 106 109, 绥阳温泉(55 m)、枧 坝 $(45 \mathrm{~m})$ 、四面山、后坝 $(30 \mathrm{~m}) ; 110$, 遵义高家崖 $(0.2 \mathrm{~m}) ; 111 \sim 113$, 泥潭永兴、牛场、兴隆场(18 m); 114 116, 余庆松烟(20 m)、肃阳(127 m)、 小思 $(127 \mathrm{~m}) ; 117$, 黄平城东; 118,119 , 凯里翁项 $(<10 \mathrm{~m}$ )、水珠 $(14 \mathrm{~m}) ; 120,121$, 贵阳乌当 $(9 \mathrm{~m})$ 、打渔; 122 124, 贵定石板寨 $(29 \mathrm{~m})$ 、马家屯、

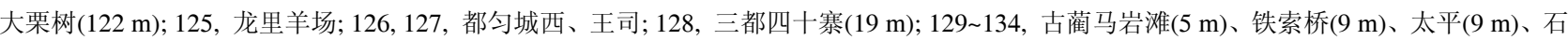
宝 $(33 \mathrm{~m}) 、$ 、坪、德耀; 135,136 , 叙永黄泥乡、水潦 $(4 \mathrm{~m}) ; 137$, 兴文古宋 $(1 \mathrm{~m}) ; 138$, 毕节沟头 $(1.3 \mathrm{~m})$. 非红层剖面: 139, 兴山古夫; 140, 巴东 思阳桥; 141, 巫溪田坝; 142, 恩施太阳河; 143, 建始官店口; 144, 145, 宣恩椒园、晓关; 146 , 利川忠路; 147, 咸丰活龙坪; 148, 149, 黔江黎 水、黑溪; 150,151 , 彭水郁山、龙射; 152, 武隆白马; 153, 南川严家坝; 154 156, 水水温水、土河、桑木场; 157, 古落渔化; 158, 兴文城北; 159, 叙永沙田头; 160 , 威信双河; 161 , 贵定阳宝山; 162, 凯里洛棉; 163,164 , 都匀马场、钱家坡; 165,166 , 独山挖那、利寨 


\section{3 川中古陆周缘区(图 3-C)}

川中古陆 ${ }^{[61]}$ (或称成都古陆 $)^{[22]}$ 3) 周缘, 已知有 4 个下红层分布区(图 3-C1 C4). 华菳山一带的白云庵 组为紫红色泥岩与灰岩互层 $(30 \sim 50 \mathrm{~m} \text { 厚 })^{[63,64]}$, 产浅 水珊瑚化石. 威远井下龙马溪组近顶部发育 $8.5 \mathrm{~m}$ 厚 的海相红层 ${ }^{[52]}$, 与其以东、以南地区的下红层遥相呼 应. 二郎山西部长岩子组的紫红色沉积, 厚 48.2 $\mathrm{m}^{[29,63]}{ }^{3)}$; 二郎山西南坡罗圈湾的下红层称红岩子组, 厚 $34.4 \mathrm{~m}^{[60] 3)}$. 这些地区都发育下红层, 但互相独立, 推测均受川中古陆制约.

\section{4 鄂豫古陆南侧区(图 3-D)}

湖北北部, 如宜城(板桥店)、钟祥(客店坡、胡家 集、朱堡埠)、京山县境北部及襄阳市西部(图 3-D), 纱 帽组中夹有紫红色与灰-黄绿色的粉砂岩、砂质页岩 及泥岩相间地层, 沉积物颗粒比上述诸地区更粗. 往 南到京山石门冲, 这套红层消失, 被黄绿色地层所替 代 ${ }^{[52]}$. 根据地层序列和区域对比, 这套红层可能也与 溶溪组相当. 因其分布呈现北厚、南薄的特点,

笔者推测它可能受控于位于更北的鄂豫古陆, 而与华夏古陆无关. 饶有趣味的是本区龙马溪组上 部也夹有紫红色页岩 ${ }^{[52]}$, 层位上显然低于下红层, 值 得今后深究.

\section{2 时代讨论}

对上扬子区下红层时代的认识有一个较长的过 程, 至今尚未定论. 最初它被确定为温洛克世 ${ }^{[28]}$, 后 被置于兰多维列世晚期 ${ }^{[15 ~ 20,22,32,33,66] 1)}$. 最近, 牙形类 和几丁虫学者对它的时代提出了两种争锋相对的意 见: 埃隆期 ${ }^{[67 ~ 69]}$ 和早特列奇期 ${ }^{[70]}$. 志留纪生物地层 对比最标准的化石是笔石 ${ }^{[71]}$, 本文拟先分析笔石资 料, 再讨论这两个重要门类的意见.

(1) 笔石. 溶溪组本身的笔石证据很少, 这就 使黔北道真巴渔韩家店组中发现的笔石显得尤为珍 贵. 那里的韩家店组近顶部, 发育 $6.35 \mathrm{~m}$ 厚的紫红色 泥岩 (下红层 $)^{[32]}$, 其下数米的地层中采获的样品, 处 理出了笔石立体标本, 被陈旭研究员鉴定为 Streptograptus nodifer ${ }^{[72]}$, 该种是 Spirograptus turriculatus 带的重要成员 ${ }^{[18]}$, 但也可延至 Monograptus crispus 带 ${ }^{[71]}$. 川中威远井下龙马溪组顶部灰绿、紫红 色泥岩(属于下红层)的下伏地层中, 找到了 $S$. turriculatus 带的笔石 ${ }^{[29]}$. 川陕边区王家湾组(紫红色 地层)盖覆在崔家沟组(S. turriculatus 带)之上, 可与 $S$. turriculatus 带上部到 M. crispus 带下部对比 ${ }^{[18]}$.

(2) 牙形类. 溶溪组中尚未寻获重要的牙形类 化石 ${ }^{[69]}$. 溶溪组的上覆地层为秀山组, 后者的下段产 Ozarkodina guizhouensis-Distomodus sp. nov. 动物群, 王成源 ${ }^{[18,19]}$ 将它归入埃隆末期-特列奇早期. 秀山组 上段所产的牙形类属于 Pterospathodus eopennatus 带, 该带的底界被认为大体位于 S. turriculatus 笔石带的 中部; 这样, O. guizhouensis 带可与欧美 D. staurognthoides 带下部对比, 后一个带纵跨埃隆阶和特列奇 阶的界线. 考虑到 D. sp. nov. 与 D. staurognathoides 形态接近, O. guizhouensis 带也被认为是纵跨上述两 个阶的 ${ }^{[69]}$. 最近, 王成源等 ${ }^{[67,}{ }^{68]}$ 将秀山组下段归于 特列奇阶底部、甚至部分划入到埃隆阶内; 并将溶溪 组归于埃隆阶上部 ${ }^{[69]}$.

(3) 几丁虫. Eisenackitina daozhenensis 和 Ancyrochitina brevicollis 在道真巴渔(韩家店组顶部)、 南江桥亭(南江组)、二郎山冷積(罗圈湾组顶部)、大 关黄葛溪和宁强城郊(崔家沟组) ${ }^{[73,74]}$ 等地常联袂产出, 耿良玉等 ${ }^{[18,75]}$ 为此建立 A. brevicollis 带, 与笔石 $S$. turriculatus 至Monoclimacis griestoniensis 带下部对比, 并将石阶雷家屯剖面埃隆阶和特列奇阶的分界划在 溶溪组下部 (TT762) 与马脚冲组下部 (TT783) 之 间 ${ }^{[22,76]}$. 考虑到 $E$. daozhenensis 的首现(FAD)低于 $A$. brevicollis(如石阶雷家屯、桐梓韩家店、宁强郊区和 凯里翁项), Tang 等 ${ }^{699}$ 新建立了 E. daozhenensis 带, 因 该带化石产自宁强城郊崔家沟组 S. turriculatus 带 ${ }^{[73]}$, 故被划入下特列奇阶 ${ }^{[70]}$.

埃隆阶和特列奇阶的牙形类与几丁虫(如对华南 特列奇阶上部 Pterospathodus celloni 带的重新认 识 ${ }^{[67,70]}$ 与几丁虫分带序列)的研究, 取得了新的进展, 有目共睹. 但是, 各带的延限及与笔石带的对比仍在 深化之中 ${ }^{[69,77]}$. 应该说, 牙形类将溶溪组归于埃隆阶 的认识, 还不是最终结论, 有待于新证据的获得, 因 为即使 P. eopennatus 带之底位于 S. turriculatus 带中 部 ${ }^{[67,68]}$, Ozarkodina guizhouensis 带的归属仍存在两 种可能性，即延至或不延到上埃隆阶。按最新意见, 在特列奇阶的范围内, S. turriculatus 带之下还有 Spirograptus guerichi 带, 后者是志留系诸多笔石带 中历程最长的一个带 $(2.4 \mathrm{Ma})^{[78]}$. 有鉴于此, 下特列 奇阶的空间留给溶溪组的可能性目前很难排除。与 
此同时, 几丁虫 E. daozhenensis 的时代也尚未确定, 因为它的已知最低层位是在桐梓韩家店的韩家店组 底部 ${ }^{[73]}$, 相当于上埃隆阶的可能性是存在的.

滇东北的大关大路寨组产秀山动物群 ${ }^{[18]}$ 和几丁 虫 Angochitina longicollis ${ }^{[73,74]}$, 与黔东北、渝东南的 秀山组上部可以对比. 这样, 嘶风崖段(下红层)与 $A$. brevicollis 和 E. daozhenensis 带对比 ${ }^{[73,74]}$, 与溶溪组 部分相当. 宜昌北部纱帽组第二段紫红色地层(下红 层 $)^{[78]}$ 上部产 A. brevicollis ${ }^{[75]}$. 鄂西䄰归杨林的纱帽 组(含下红层)上部产牙形类 $P$. eopennatus ${ }^{[67,68]}$, 将它 归于下特列奇阶与本文观点并不相悖.

讨论下红层的时代, 需进一步分析其上覆和下 伏地层的时代. 1) 溶溪组位于秀山组之下, 其上段产 秀山动物群被对比到 M. griestoniensis 带上部到 Oktavites spiralis- Stomatograptus grandis 带(特列奇 阶中上部 $)^{[18]}$. 介于溶溪组和秀山组上段之间的秀山 组下段, 厚度多在 110 220 m之间, 该期沉积速率快, 时限不长, 向下延续并占领 M. griestoniensis 带下部, M. crispus 带, S. turriculatus 带和 Spirograptus guerichi 带的可能性不大. 2) 在石阶-印江-秀山-龙山 凹陷带内, 溶溪组之下的志留纪地层包括小河坝组 和龙马溪组, 后者上部产 Lituigraptus convolutus 带笔 石, 属于埃隆阶中部. 从这个凹陷带向西, 到黔北-渝 南酒店垭背斜东西两翼的桐梓松坎韩家店和綦江观 音桥 ${ }^{[18] 3)}$, 韩家店组中下部仅发育 7 8 $\mathrm{m}$ 的浅水红层, 与龙马溪组上部(相当于埃隆阶中部 Campograptus communis 带的一部分)之间, 为韩家店组下段(80 90 $\mathrm{m}$ )和石牛栏组(石牛栏段和松坎段: 230 265 m), 总 厚度超过 $320 \mathrm{~m}$. 这段地层宜归于埃隆阶上部和特列 奇阶底部, 故将韩家店组中的浅水红层划入埃隆阶 中上部 ${ }^{[68]}$ 目前还难以置信.

以上分析表明, 尽管各地下红层在地理分布上 受同一或不同古陆的控制, 且其顶、底界穿时, 但置 于下特列奇阶更可接受(图 6). 这些近岸、浅水海相 红层的出现, 反映了当时上扬子区特定的古地理和 沉积环境.

\section{3 沉积环境与形成条件探讨}

扬子区志留系的下红层分布区涵盖了有所差异 的沉积环境, 但一直被认为都属于海相沉积范 畴 ${ }^{[15,17,44]}$. 棘鱼类和软骨鱼类 Sinacanthus, Dayong- aspis, Hanyangaspis 等与其他化石相伴发现, 即是海 相产物的证据 ${ }^{[79 ~ 85]}$. 与这些类似的组合还见于鄂东 南 ${ }^{[83,86-88]}$ 、贑北 ${ }^{[89]}$ 和皖南 ${ }^{[50,90]}$. 在不同地点的溶溪组 及其相当层位, 主要产自与紫红色地层互层或夹层 中的黄绿、蓝灰色地层中, 还发现过树形笔石 (Hunanodendrum typicum)、腕足类、珊瑚、三叶虫、 海百合、苔藓虫、當类等, 这些化石类群虽说数量少 且种类单调, 但都是典型的海洋生物 ${ }^{[15,23,28,42] 1)}$. 湘 西永顺等地溶溪组黄绿色泥岩中, 含有少量单调的 磷酸盐质腕足动物, 滇东大关和巧家的嘶风崖段产 四射珊瑚 ${ }^{[51]}$ 、腕足类(据詹仁斌、李贵鹏面告)等化石, 说明上述地区的下红层确实属于浅水海相沉积, 但 各地水域深度不尽相同，大致包括正常和非正常两 种海相环境, 前者多见于非红色沉积, 后者如淡化海 常见于红色沉积中.

志留系特列奇阶下部(Spirograptus guerichi 带至 Monograptus crispus 带)的海相红层, 不仅在国内广 泛分布, 在国外也有很多记载, 如美国、英国、爱尔 兰、爱沙尼亚、拉脱维亚、挪威等地. 欧美学者曾强 调那里的志留纪早期海相红层是在海侵状态下形成 的 ${ }^{[55,56]}$. 但是, 本文的研究结果, 并不赞同海侵是上 扬子区下红层形成的必要条件的观点, 而是支持下 红层是在海平面下跌过程中沉积的认识 ${ }^{[22,34]}$. Johnson 等 ${ }^{[11,92]}$ 、 Haq 和 Schutter ${ }^{[93]}$ 认为全球特列奇 早期的海平面，尽管有一个复杂的变化过程，但基本 上在 $S$. guerichi 带之初起开始上升, 到 M. crispus 带 时下跌. 而从区域上看, 上扬子海域的沉积环境和生 物群落的证据表明, 下红层沉积时(特列奇早期)的海 平面总体上是下降的. 所以, 本文研究的实例难以解 释红层与海侵相关的论断.

在史前陆生植物尚未占领古陆之前, 如志留纪 早期, 古陆源区无植被覆盖, 地表岩石易于遭受风化 剥蚀. 就华南而言, 奥陶纪晚期至志留纪早期, 正是 华夏与扬子两个块体“陆陆拼合碰撞”的强烈活动期, 该碰撞发生在华南东部, 指示华夏古陆东高、西低的 地理走势. 1995 年, 王泽忠 ${ }^{[44]}$ 首次提出湘西北永顺龙山地区志留系下部的小河坝组和溶溪组分别代表 三角洲前缘相和三角洲平原相的认识, 推测官仓北 科甲湖和勺哈北骑斗湖的溶溪组上部发育紫红色中 厚层、透镜状的粉砂岩和细砂岩, 横向上在 $20 \sim 100 \mathrm{~m}$ 的范围内尖灭, 还发育小型交错层理和水流波痕, 属 于分流河道沉积. 上述认识值得重视. 笔者根据所掌 


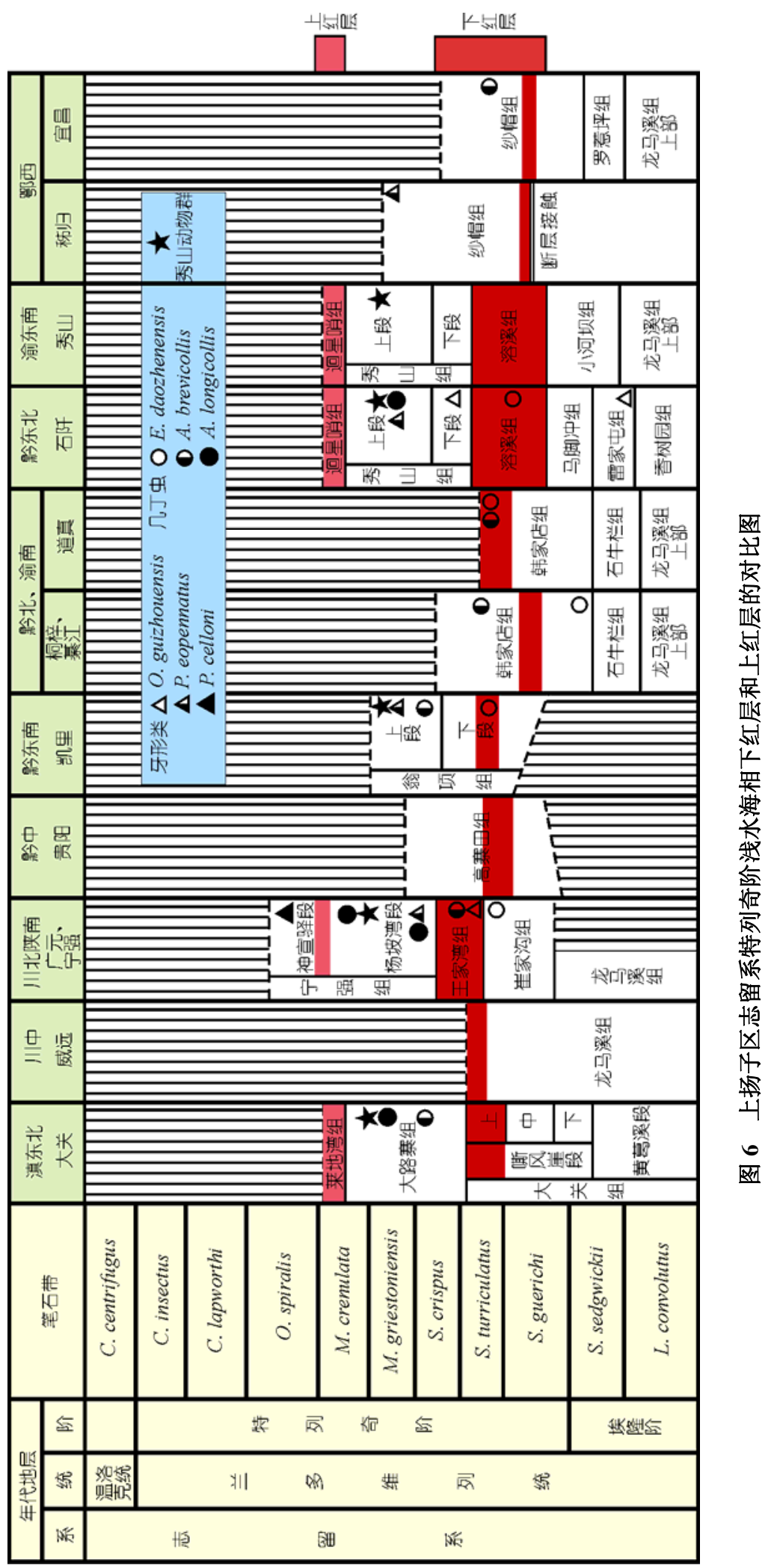


握的资料认为, 推测古陆上发育河流是有道理的, 其 原因包括: 1) 志留纪早期华夏古陆东高、西低的古地 貌 ${ }^{[15,17,23]}$ 特征明显, 为河流的产生提供了古地理背景; 2) 从古气候考虑, 当时华夏古陆位于热带-亚热带地 区 $^{[94]}$, 雨量充沛、水量充足, 百川汇合, 形成主干河 流的可能性很大；3）在地层序列上, 除龙马溪组底 部(若干个笔石带)的沉积速率很低外 ${ }^{[95]}$, 往上的龙马 溪组中上部、小河坝组和溶溪组均显示了较高的沉积 速率, 巨厚细碎屑岩层很可能是由流量可观的大型 河流提供大量物质的产物; 4) 在岩石性质上, 溶溪 组多发育薄层至中厚层泥岩、粉砂岩夹细砂岩, 而灰 岩的夹层或透镜体几乎不见; 5) 在沉积构造上, 湘 西北广泛见及的流水波痕、交错层和有些地点发育的 泥裂表明该区很可能属于三角洲平原相 ${ }^{[44]}$;6) 在生 物组合上, 湘西北的溶溪组, 总体上化石稀少, 紫红 色地层中的化石更为罕见, 形态多样的痕迹化石指 示了近岸、很浅、盐度不正常的沉积环境, 低盐度的 海域很可能是由河流注入大量淡水的结果. 如果上 述认识可靠, 华夏古陆当时可能存在一条(甚或多条) 规模较大的河流, 它(或它们)由东向西、携带着大量 的泥沙和淡水流入扬子海盆; 如果再发育富含高价 铁(可能来自地幔柱和火山岩浆)的岩石, 那么该河流 致使海水淡化过程中, 还携带着大量细粒富铁质的 泥沙、冲入扬子海域并使其沉积在河流的出海口及其 附近海域底部, 包括近岸滨-浅海环境、三角洲相. 在 源区或被河流搬运甚至沉积过程中, 这些沉积物一 直保持着氧化的状态. 于是, 就沉积了溶溪组及其相 当地层; 这也正是溶溪组最发育、红层厚度最大的地 区. 上述假说有别于 Ziegler 和 McKerrow ${ }^{[55]}$ 提出的北 美志留纪特列奇期浅水海相红层源自含氧化铁海岸 带风化剥蚀并被海水淹没的观点. 华夏古陆作为源 区且不断隆升扩大和发育大规模河流系统, 是黔川 湘鄂渝边区下红层的形成最关键的背景条件, 对下 红层的发育起着直接的制约作用.

下红层的发育状况不仅与古陆的距离有关, 还 与海底地形和沉降幅度有关. 本区特里奇早期海域 沉积速率很快, 是下红层形成的重要背景条件. 快速 堆积足以阻止底域水界面下的沉积物的还原, 使其 处于氧化状态, 含高价铁 $\left(\mathrm{Fe}_{2} \mathrm{O}_{3}\right)$ 的细屑物来不及还 原即被快速埋藏. 海盆在一边快速下沉、一边快速堆 积、两者速率大致持平的情况下, 海水深度长期保持
在数米至 $20 \mathrm{~m}$ 内. 沉积构造能指示当时的海域环境, 溶溪组保存了浅水沉积的诸多特征, 诸如干裂纹(如 永顺吊井岩乡北)、对称和不对称的波痕(如石阡雷家 屯)、小型或大型交错层理(如秀山溶溪); 少数层位富 含属种单调的化石组合(如石阡雷家屯的双壳类, 宜 昌军田坝的介形虫 ${ }^{[33]}$ ); 这些均指示了三角洲和近岸 潮坪的沉积特点 ${ }^{[15,44,53] 1)}$.

本区发育的下红层并非都是紫红色的. 黄绿或 蓝灰色的泥岩、粉砂岩和细砂岩(有机质含量和铁质 含量甚少, 处于相对较弱的还原条件)总是与红色地 层交互出现, 唯独各自的厚薄不一, 层数有别, 说明 当时海底沉积物和水体之间的界面上、下并非一直处 于富含高价铁、强氧化的条件下, 而是在强氧化与弱 还原相互交替的过程之中.

古气候是否会对红层成因有所影响? 欧美学 者 ${ }^{[55]}$ 曾强调特列奇早期发育的海相红层是在炎热干 旱的气候环境下形成的. 早特列奇早期的华南板块 位于南半球低纬度海域 ${ }^{[89]}$. 耿良玉等 ${ }^{[22]}$ 认为冰川活 动是红层形成的主要原因. 尽管这个时期全球气候 和海水温度尚不明了, 但之前的石牛栏组(埃隆中晚 期)富含四射和床板珊瑚及介壳风暴堆积(如 Paraconchidium 层) $)^{[96]}$ 可能属于相对暖水的产物; 这样, 下红 层沉积时的海水温度比前期略为低些的推测似乎可 以被接受. 但是下红层是否反映当时气候和水温变 冷, 值得进一步深究.

上扬子区位于华夏古陆西北的前陆盆地 ${ }^{[44,97,98]}$, 当时的海盆边快速沉降、边接受大量堆积, 海域处于 海平面下降期, 缺少上升洋流, 有机质生产量低下, 营养物质贫㾑, 生物多样性不高(无脊椎动物属种总 量不足前期之半), 下红层正是在这样的浅水 (以 BA1 2 为主)、透光带内、海底处于强氧化(紫红色地 层)和弱还原(黄绿、蓝灰色地层)交替的条件下沉积的 (图 7).

\section{4 比较与讨论}

根据上述分析，现将上扬子区志留系下特列奇 阶的红层分别与国外同期及白严系的海相红层进行 比较, 从中揭示不同时期、不同地区的海相红层之间 存在的共性与差异性. 它们的共性是都在含高价铁、 寡营养、低生产量、极低的有机碳和磷物质、较强的 


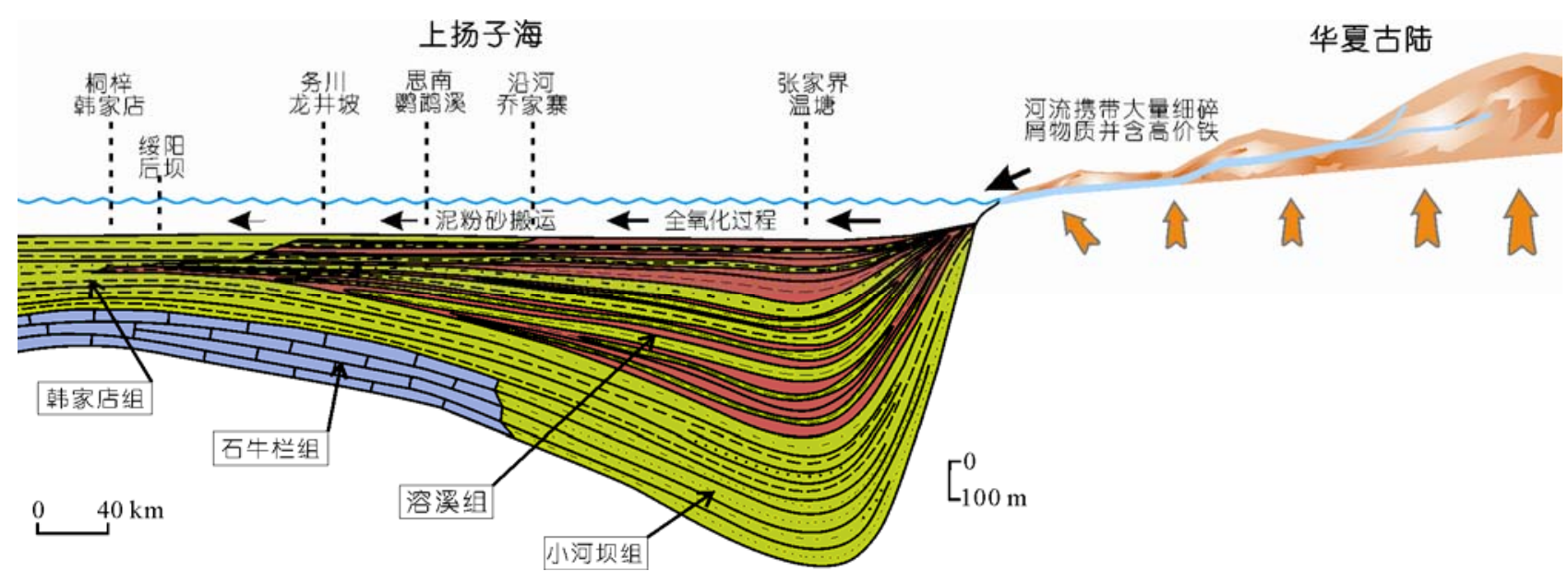

图 7 示上扬子海域 A 区志留系下特列奇阶浅水海相红层的形成与华夏古陆的关系

氧化环境(温度可能不高)下形成的，而它们之间的差 异则更引人瞩目.

\section{1 与欧美特列奇早期海相红层的比较}

西欧和北欧所发育的特列奇阶海相红层, 属于 远岸、外陆棚或斜坡、较深水的产物 ${ }^{[35,99]}$, 含较深水 的笔石 (如 $S$. turriculatus) 和腕足类 (BA4 5, 如 Costistricklandia 群落或 Clorinda 群落), 与上扬子区 同期海相红层不一样. 以爱沙尼亚为例, 从荣姆巴组 (Rumba Formation)到维里斯组(Velise Formation)的 红层, 主要是由于上升和下降洋流使海底及沉积物 中生产量与含氧量发生了变化. 埃隆晚期: 处于上升 洋流、底域还原环境(黑色页岩和散布的黄铁矿), 使 陆棚生产量高且缺氧; 特列奇早期: 下降洋流带入富 氧、贫营养表层水, 海底充氧(赤铁矿和少量针铁矿), 生产量低, 海水-沉积物界面被氧化, 沉积厚度较 小 ${ }^{[99]}$. 两个时期的变化有相似之处, 但上扬子区红层 的地理分布则与古陆关系密切, 生物组合多为近岸、 固着底栖无脊椎动物和河口游泳的脊椎动物, 堆积 厚度大, 水深可能只有数米至十余米 $(\mathrm{BA} 1 \sim 2)^{[23,34]}$.

美国阿帕拉契亚山区志留系特列奇阶的海相红 层, 也是内陆棚、较浅水的产物, 所含化石都属于 Eocoelia 腕足动物群落(BA2) ${ }^{[55]}$, 其富氧化、缺还原 的条件及含铁量高、含有机质量低、沉积物颗粒细、 沉积速率快、时限短等特点, 与上扬子区的情况相似. 两者的区别在于美国克林腾 (Clinton) 红层沉积物是 由于海水侵漫充分氧化和较疏松的上奥陶统岩层风 化剥蚀的结果, 与本区海退产物的下红层不同.

\section{2 与白严纪海相红层的比较}

最新研究表明, 白严系海相红层多为远洋、深水 沉积, 堆积在大陆边缘、斜坡和洋盆底, 水深超过 200 1000 m, 尽管陆表海和大洋盆地的沉积时限不 一, 总体历程约 20(Ma), 各地红层延续基本在 $3 \sim 8(\mathrm{Ma})^{[100]}$, 沉积速率都很低(平均 13 14 m/Ma) ${ }^{[8]}$, 沉积岩多以灰岩为主, 常含燧石结核和硅质岩 ${ }^{[101]}$, 泥量较少, 生物以浮游类型的有孔虫、放射虫等为 主 $^{[4,6,9]}$, 无浅水沉积构造记录 ${ }^{[4]}$. 而上扬子区下红层 的分布则受制于古陆位置, 时限较短, 沉积速率较快 $(100 \sim 200 \mathrm{~m} / \mathrm{Ma}$, 为前者的 7 15 倍), 沉积物颗粒细 (多泥岩、粉砂岩), 水深常不超过 $20 \mathrm{~m}$ (BA1 2 $)^{[23,34]}$, 生物以近岸、浅水底栖固着类型的无脊椎动物和近岸 河口游泳的脊椎动物为特征. 以上分析表明两者在 很多方面存在着显著的差异.

\section{5 结语}

海相红层或黑色页岩, 一红、一黑, 氧化或还原, 富含高价铁或有机碳，分别代表两个基本不相容的 沉积与地质环境. 它们可以在同一地区、异时出现, 也 可以在不同地区、同时存在. 假如缺失特定的古地 理、古海洋、古沉积、古构造和古气候条件, 特别是 没有古陆，上扬子区志留系浅水海相红层是不可能 发育的. 就特列奇早期而言，上扬子海域周缘古陆的 状态(升隆与扩大)是下红层形成的古地理背景;由河 流携带含高价铁细碎屑物是下红层沉积的物质供给 条件；近陆海底和沉积物界面的氧化作用是下红层 
形成的关键环境. 此外, 当时海域还发育一系列与上 述相伴的环境条件, 诸如海平面下跌、上升洋流缺 乏、营养物贫㾑、有机生产量低、生物多样性不高、 海盆下沉和沉积速率较快, 使得高价铁未及还原便堆 积下来. 这些沉积特点与欧洲同期远岸陆棚、较深水 沉积的红层不同, 与华南奥陶纪远岸、较深水的红层 (如紫台组)也不同, 更与白严纪深得多、静得多、沉积 速率慢得多、沉积环境稳定得多的大洋深水红层不同.

整个古生代从寒武纪初到二叠纪末 ${ }^{[102]}(542 \sim 252$ $\mathrm{Ma}$ ), 历时近 3 亿年, 全球多处于温室效应之下, 也 数次被冰期 (如奥陶纪末的短冰期和石炭-二叠纪的 长冰期)所打断. 黑色页岩的广布常被解释为与海洋 生产量和有机碳埋藏量大增而引致大气二氧化碳含 量快速下降有关联 ${ }^{[103 ~ 105]}$, 同时, 浮游植物生产量也 大为增加 ${ }^{[73,106]}$. 如此说来, 1) 氧化条件的广布和海 相红层的发育, 是否与大气二氧化碳含量的剧增密 切相关? 2) 华南志留纪特列奇早期(海相红层)是否 比埃隆期(黑色笔石页岩)的海水温度低、从而说明浅 水海相红层的形成与气候变凉有关? 若两者是相关 的, 大气二氧化碳含量理应降低, 与第一点相悖, 又 做怎样的解释? 3) 海相红层在很多地质时代都有存 在, 唯其发育程度、堆积环境和范围有所不同, 从时 空分布考虑, 华南古生代浅水海相红层最发育的地 质时期是志留纪和三叠纪; 志留纪时, 陆地植被尚未 发育; 三叠纪时, 经过二叠纪末大灭绝后陆生植物也 遭遇大劫, 那么, 近岸浅水红层是否与陆地植被的发 育状况有着某种联系? 4) 红色沉积所富含的高价铁
细屑物, 究竟是由物理作用(如河流携带)、异地氧化 或原地海底地球化学作用, 或共同产生? 甚至还有 细菌生物参与活动? 目前还欠缺对关键剖面紫红色 层和黄绿、蓝灰色层的对比研究. 以上问题, 远未破 解, 值得深入探讨.

海相红层的研究涉及到区域乃至全球史前地质 系统及其环境演变的综合问题. 本文只是对上扬子 区志留纪早期下红层的时空分布进行初步总结, 并 尝试对其成因作初步分析, 故只是个起步. 要深入探 索这些海相红层的性质和成因背景, 还需在不断加 强生物地层工作的基础上, 对不同地区和剖面的下 红层进行深入的岩石学和矿物学(如对紫红以及黄 绿、蓝灰等不同颜色的地层所含矿物, 如含铁量和价 态进行对比研究)、沉积学(如红层的沉积特征及所含 沉积构造的识别与解释)、地球化学(如红层是原地氧 化还是异地氧化与保存的产物, 包括有机地化和生 物有机地化)、古地理学(如华夏古陆的边界、地形地 貌、隆升和扩展、古河流的发育、上扬子海域的海底 地形)、古海洋学(如海域范围和深度, 海洋上升和下 降洋流的识别)、古气候学(如红层沉积与气候变凉或 变热的关联)、大地构造学(如华南大构造背景、活动 状态及其节律)等领域的学科交叉和综合研究. 本文 的年轻学者正在对志留纪早期浅水海相红层(含红色 和非红色地层)的岩石矿物学和地球化学作进一步分 析, 拟为解释华南志留纪红层的成因机制, 进而探索 当时的古海洋环境、古气候、古地理、古构造等方面 的问题, 提出新的证据和认识. 吉琐、王成善、焦惠亮、王成源、史晓颖诸位老师提供重要资料或建议; 评审人对文稿提出宝贵的建设性意 见. 本文是 IGCP 519 的成果之一。

\section{参考文献}

1 王成善, 胡修棉, 李祥辉. 古海洋溶解氧与缺氧与富氧问题研究. 海洋地质与第四纪地质, 1999, 19: 42-50

2 胡修棉. 藏南白严系沉积地质与上白严统海洋红层一一大洋富氧事件. 成都: 成都理工大学出版社, 2002. 216

3 魏玉帅, 王成善. 土耳其-高加索-喜马拉雅一线白严纪大洋红层对比. 地学前缘, 2005, 12: 51-59

4 Wang C S, Hu X M, Jansa L F, et al. Upper Cretaceous oceanic anoxic event in southern Tibet. Cretac Res, 2005, 26: 43-48

5 Wang C S, Hu X M, Huang Y J, et al. Overview of Cretaceous Oceanic Red Beds (CORBs): A window on global oceanic and climate change. In: Hu X M, Wang C S, Scott R W, et al, eds. Cretaceous Oceanic Red Beds: Stratigraphy, Composition, Origins, and Paleoceanographic and Paleoclimatic Significance. SEPM Spec Publ, 2009, 91: 13-33 
6 Wang C S, Hu X M, Huang Y J, et al. Cretaceous oceanic red beds as possible consequence of oceanic anoxic events. Sediment Geol, 2011, 235: $27-37$

7 胡修棉, 王成善, 李祥辉, 等. 藏南上白严统大洋红层: 岩石类型、沉积环境与颜色成因. 中国科学 D 辑: 地球科学, 2006, 36: $811-821$

8 Scott R W. Chronostratigraphic datbase for Upper Cretaceous oceanic red beds (CORBS). In: Hu X M, Wang C S, Scott R W, et al, eds. Cretaceous Oceanic Red Beds: Stratigraphy, Composition, Origins, and Paleoceanographic and Paleoclimatic Significance. SEPM Spec Publ, 2009, 91: 35-57

9 Hu X M, Wang C S, Scott R W, et al. Cretaceous oceanic red beds: stratigraphy, composition, origins, and paleoceanographic and paleoclimatic significance. In: Hu X M, Wang C S, Scott R W, et al, eds. Cretaceous Oceanic Red Beds: Stratigraphy, Composition, Origins, and Paleoceanographic and Paleoclimatic Significance. SEPM Spec Publ, 2009, 91: 13-33

10 张文堂. 中国的奥陶系. 北京: 科学出版社, 1962. 161

11 穆恩之, 朱兆玲, 陈均远, 等. 西南地区的奥陶系. 见: 中国科学院南京地质古生物研究所, 编著. 西南地区碳酸盐生物地层. 北京: 科学出版社, 1979. 108-154

12 张允白, 周志毅, 张俊明. 扬子陆块早奥陶世末期-中奥陶世. Darriwilian 初期沉积分异. 地层学杂志, 2002, 26: 302-314

13 汪隆武, 许红根, 齐岩辛, 等. 浙贑交界地区上奥陶统红家坞组 $\left(\mathrm{O}_{3} h\right)$. 地层学杂志, 2004, 28: 52-55

14 吴荣昌, 詹仁斌, 李贵鹏, 等. 浅论华南扬子区下、中奥陶统紫台组. 地层学杂志, 2007, 31: 325-332

15 葛治洲, 戎嘉余, 杨学长, 等. 西南地区的志留系. 见: 中国科学院南京地质古生物研究所, 编著. 西南地区碳酸盐生物地层. 北京: 科学出版社, 1979. 155-220

16 戎嘉余, 陈旭, 王成源, 等. 论华南志留系对比的若干问题. 地层学杂志, 1990, 14: 161-177

17 周名鬼, 王汝植, 李志明, 等. 中国南方奥陶-志留纪岩相古地理与成矿作用. 北京: 地质出版社, 1993. 110

18 陈旭，戎嘉余. 中国扬子区兰多维列统特列奇阶及其与英国的对比. 北京: 科学出版社, 1996. 162

19 王成源. 华南志留系红层的时代. 地层学杂志, 1998, 22: 127-128

20 王成源. 云南曲靖地区关底组的时代. 地层学杂志, 2001, 25: 125-127

21 王成源, 王平, 杨光华, 等. 四川盐边稗子田志留系牙形刺生物地层的再研究. 地层学杂志, 2009, 33: 302-317

22 耿良玉，王玥，张允白，等. 扬子区后 Llandovery 世(志留纪)胞石的发现及其意义. 微体古生物学报, 1999, 16: 111-151

23 Rong J Y, Chen X, Su Y Z, et al. Silurian paleogeography of China. In: Landing E, Johnson M E, eds. Silurian Lands and Seas-Paleogeography Outside of Laurentia. New York State Mus Bull 493, 2003. 243-298

24 范德廉, 张涛, 叶杰, 等. 中国的黑色岩系及其有关矿床. 北京: 科学出版社, 2004. 441

25 穆恩之. 中国的志留系. 北京: 科学出版社, 1962. 95

26 周志毅, 陈丕基. 塔里木生物地层和地质演化. 北京: 科学出版社, 1990. 366

27 尹赞勋, 陈庆宣, 李璞, 等. 祁连山区地质研究的新收获. 科学通报, 1958, 3: 113-115

28 中国科学院南京地质古生物研究所. 西南地区地层古生物手册. 北京: 科学出版社, 1974. 454

29 林宝玉, 郭殿珩, 汪啸风. 中国地层 6, 志留系. 北京: 地质出版社, 1984. 245

30 黄冰, 戎嘉余, 王怿. 黔西赫章志留纪晚期小莱采贝动物群的发现及其古地理意义. 古地理学报, 2011, 13: 30-36

31 龚联珗. 对贵阳乌当志留系高寨田群下亚群岩石地层划分、对比的新意见. 贵州地质, 1987, 10: 61-64

32 龚联玞. 黔北韩家店群的时代及其对比. 地层学杂志, 1986, 10: 315-319

33 龚联瓒. 关于贵州北部和黔东南志留系岩石地层划分对比和统一名称问题. 贵州地质, 1990, 25: 313-323

34 戎嘉余, 马科斯·约翰逊, 杨学长. 上扬子区早志留世(兰多维列世)的海平面变化. 古生物学报, 1984, 23: 672-694

35 戎嘉余. 生态地层学的基础-群落生态的研究. 见: 中国古生物学会, 编. 中国古生物学会第十三、十四届学术年会论文集. 合肥: 安徽科学技术出版社, 1986. 1-24

36 Johnson M E, Rong J Y, Yang X C. Intercontinental correlation by sea-level events in the Early Silurian of North America and China (Yangtze Platform). Bull Geol Soc Amer, 1985, 96: 1384-1397

37 Wang Y, Boucot A J, Rong J Y, et al. Community Paleoecology as a Geologic Tool: The Chinese Ashgillian-Eifelian (latest Ordovician through early Middle Devonian) as an example. Spec Pap Geol Soc Amer, 1987, 211: 1-100

38 金淳泰, 万正权, 叶少华, 等. 四川广元、陕西宁强地区志留系. 成都: 成都科技大学出版社, 1992.97

39 熊永先, 罗正远. 古萄珙县间地质矿产. 四川地质调查所地质从刊, 1939, 2: 83-150

40 Yin Z X. Tentative classification of Silurian rocks of South China. Bull Geol Soc China, 1949, 29: 1-61

41 穆恩之, 陈旭, 倪寓南, 等. 中国志留纪地层对比表及说明书. 见: 中国科学院南京地质古生物研究所, 编著. 中国各纪地层对比表 及说明书. 北京: 科学出版社, 1982. 73-89 

Geol, 2004, 53: 94-124 49: $10-28$ 2010, 21(Spec Issue): 52-57 Wales, 1984, 107: 419-441

四川省区域地层表编写小组. 西南地区区域地层表, 四川省分册. 北京：地质出版社, 1978. 328

熊永先，彭国庆．涪陵彭水间铁矿地质．四川省地质调查所地质从刊, 1943, 5: 43-96

王泽中. 湘西北永顺-龙山地区早志留世三角洲沉积. 高校地质学报, 1996, 2: 400-408

丁传谱，区元任，敖振宽，等. 湘西北的志留系. 中南矿业学院学报, 1959, 4: 19-37

葛治洲, 戎嘉余, 杨学长, 等. 西南地区志留系十条剖面资料. 地层古生物, 1977, 8: 92-111

贵州地层古生物工作队，西南地区区域地层表，贵州省分册。北京：地质出版社, 1977.604

秦鸿宾. 贵阳附近志留纪化石的新资料. 古生物学报, 1956, 4: 621-640, 679-685

Ting V K. Notes on the stratigrphy of the Spirifer tingi beds of Kueiting. Bull Geol Soc China, 1930, 9: 240-247

王士涛, 夏树芳. 安徽巢湖志留纪无领类及鱼化石的发现及其地层意义. 中国地质科学院地质研究所所刊, 1980, 1: 101-112

陈建强, 何心一. 滇东北大关地区志留纪兰多维列世晚期(Telychian 期)的四射珊瑚动物群. 古生物学报, 2005, 44: 229-246

中南地区区域地层表编写小组. 中南地区区域地层表. 北京：地质出版社, 1974. 534

陈立德, 陈孝红, 李志宏, 等. 志留系. 见: 汪啸风, 陈孝红, 张仁杰, 主编. 长江三峡地区珍贵地质遗迹保护和太古宙-中生代多重 地层划分与海平面升降变化. 北京: 地质出版社, 2002. 101-130

汪啸风, 倪世钊、曾庆銮, 等. 长江三峡地区生物地层学(2), 早古生代分册. 北京: 地质出版社, 1987. 640

Ziegler A M, McKerrow W S. Silurian marine red beds. Amer J Sci, 1975, 275: 32-56

Kiipli E. Redox changes in the deep shelf of East Baltic Basin in Aeronian and early Telychian (Early Silurian). Proc Estonian Acad Sci

Kiipli E, Kallaste T, Kiipli T. Hematite and goethite in Telychian marine red beds of the East Baltica. GFF, 2000, 122: 281-286

周铁明. 云南盐津地区的志留系. 地层学杂志, 1982, 6: 161-173

兰朝华. 滇东北大关地区志留系层序. 见: 云南地质学会地层古生物文集. 昆明: 云南省地质科学研究所, 1979.71-88

金淳泰, 叶少华, 江新胜, 等. 四川二郎山地区志留纪地层及古生物. 成都地质矿产研究所所刊, 1989, 11:1-224

陈旭, 戎嘉余, 伍鸿基, 等. 川陕边境广元宁强间的志留系. 地层学杂志, 1991, 15: 1-25

金淳泰, 万正权, 陈继荣. 上扬子地台西北部志留系研究新进展. 特提斯地质, 1997, 21: 142-181

周希云, 余开富. 四川南江、城口、岳池等地早志留世牙形刺的发现. 地层学杂志, 1984, 8: 67-70

周希云. 四川华菳山地区志留系床板珊瑚及其古生态特征. 见: 石油地质古生物会议论文集编委会, 编. 石油地质古生物会议论文 集. 北京: 地质出版社, 1987.63-72

戎嘉余. 扬子区和江南区部分. 见: 林宝玉，苏养正，朱秀芳，等编. 中国地层典《志留系》. 北京：地质出版社, 1998. 104

Mu E Z, Chen X, Rong J Y, et al. Correlation of the Silurian Rocks of China. Spec Pap Geol Soc Amer, 1986, 202: 1-80

王成源, 陈立德, 王怿, 等. Pterospathodus eopennatus (牙形刺)带的确认与志留系纱帽组的时代及相关地层的比. 古生物学报, 2010,

68 王成源. 再论华南志留系红层的时代. 地层学杂志, 2011, 24: 440-447

Tang P, Xu H H, Wang Y. Chitinozoan-based age of the Wengxiang Group in Kaili, southeastern Guizhou, Southwest China. J Earth Sci,

70 Wang C Y, Aldridge R J. Silurian conodonts from the Yangtze Platform, South China. Spec Paper Palaeont, 2010, 83: 1-136

Chen X. The Silurian graptolite zonation of China. Can J Earth Sci, 1984, 21: 241-257

陈旭. 论卷笔石(Streptograptus)及其古生态. 见: 中国古生物学会, 编著, 中国古生物学会第十三、十四届学术年会论文选集. 合肥: 安徽科学技术出版社, 1986. 115-137

耿良玉. 贵州道真巴渔、湖北宜昌大中坝下志留统几丁虫化石. 古生物学报, 1986, 25: 117-128

Geng L Y, Qian Z S, Ding L S, et al. Silurian chitinozoans from the Yangtze region. Palaeoworld, 1997, 8: 1-152

耿良玉, 蔡习尧. 扬子区志留纪兰多维列统胞石序列. 古生物学报, 1987, 27: 249-257

耿良玉. 黔北石阶雷家屯志留系埃隆阶-特列奇阶界线附近几种胞石之记述. 古生物学报, 1990, 29: 623-636

Mãnnik P. An updated Telychian (Late Llandovery, Silurian) condont zonation based on Baltic faunas. Lethaia, 2007, 40: 45-60

Sadler P M, Cooper R A, Melchin M. High-resolution, early Paleozoic (Ordovician-Silurian) time scale. GSA Bull, 2009, 121: 887-906

Zhu M. Early Silurian Sinacanthus (Chondrichthyes) from China. Palaeontology, 1998, 41: 157-171

刘时藩. 塔里木西北的中华棘鱼化石及地质意义. 古脊椎动物学报, 1995, 33: 85-98

Wang N Z. Thelodont, acanthodian, and chondrichthyian fossils from the Lower Devonian of Southwest China. Proc Linn Soc New South

2 Wang N Z. Silurian and Devonian jewless craniates (Galeaspida, Thelodonti) and its habitats. Bull N Mus Nat Hist Paris, 1995, 17: 57-84 曾祥渊. 湘西溶溪组的棘鱼化石及其层位. 古脊椎动物学报, 1988, 24: 287-295 


\section{集. 北京: 地质出版社, 1978.63-67}

$$
\text { M E, eds. Silurian Cycles, Linkages of Dynamic Stratigraphy with Atmospheric, Oceanic, and Tectonic Changes. New York State Mus }
$$
Bull, 1998, 491: 3-13

93 Haq B U, Schutter S R. A chronology of Paleozoic sea-level changes. Science, 2008, 322: 64-68

94 Boucot A J, 陈旭, Scotese C R. 显生宙全球古气候重建. 北京: 科学出版社, 2009. 1-173

95 Chen X. Influence of the late Ordovician glaciation on basin configuration of the Yangtze platform in China. Lethaia, 1984, 17: 51-59

96 李越, 戎嘉余. 黔北志留纪早期枝线贝类介壳层的风暴沉积特征. 科学通报, 2007, 52: 1158-1167

97 尹福光, 许效松, 万方, 等. 华南前陆盆地演化过程中的沉积响应. 地球学报, 2001, 22: 425-428

98 尹福光, 许效松, 万方，等. 加里东期上扬子区前陆盆地演化过程中的层序特征与地层划分. 地层学杂志, 2002, 26: 315-319

99 Kiipli E. Modelling seawater chemistry of the East Baltic basin in the Late Ordovician and Early Silurian. In: Natural and Exact Sciences B42. Tallinn University of Technology Press, 2005. 158

100 万晓樵, 李国彪, 司家亮. 西藏南部晚白严世-古新世大洋红层的分布与时代. 地学前缘, 2005, 12: 31-37

101 陈曦, 王成善, 李祥辉, 等. 阿尔卑斯-喀尔巴阡上白严统大洋红层特征与对比. 地学前缘, 2005, 12: 61-68

102 Shen S Z, Crowly J L, Wang Y, et al. Calibrating the end-Permian mass extinction. Science, 2011, 334: 1367-1372

103 Brenchley P J, Marshall, J D, Carden G A F, et al. Bathymetric and isotope evidence for a short-lived late Ordovician glaciation in a greenhouse period. Geology, 1994, 22: 295-298

104 Brenchley P J, Carden G A F, Marshall J D, et al. Environmental changes associated with the 'First Strike' of the late Ordovician mass extinction. Modern Geol, 1995, 20: 69-82

105 Negri A, Ferretti A, Wagner T, et al. Phanerozoic organic-carbon-rich marine sediments: Overview and future research challenges. Palaeogeogr Palaeoclimat Palaeoecol, 2009, 273: 218-227

106 Achab A, Paris F. The Ordovician chitinozoan biodiversification and its leading factors. Palaeogeogr Palaeoclimat Palaeoecol, 2007, 245: $5-19$ 